\title{
Art of Therapy Melalui Proses Kreatif Menggambar Untuk Anak Usia Dini di Kota Bandung
}

\section{Art of Therapy Through the Creative Process of Drawing for Early Childhood at Bandung City}

\author{
Nina Nursetia Ningrum \\ Universitas Telkom, Bandung, Jawa Barat, Indonesia \\ ninanningrum@telkomuniversity.ac.id
}

Naskah diterima tanggal 12/02/2021, direvisi akhir tanggal 07/07/2021, disetujui tanggal 07/08/2021

\begin{abstract}
Abstrak
Kemampuan anak-anak dalam bertanggung jawab dan meningkatkan kepercayaan diri di Yayasan An-Nur Bandung masih belum berkembang secara optimal oleh karena itu peneliti menerapkan metode AOT melalui pembelajaran menggambar. Masalah penelitian ini yaitu: 1) bagaimana konsep AOT dalam program seni rupa? 2) bagaimana prosedur belajar mengajar melalui konsep AOT? 3) hasil yang ingin dicapai dari konsep AOT dalam program seni rupa?. Penelitian ini bertujuan untuk melihat bagaimana anak dapat merespon dan bertanggung jawab saat kegiatan pembelajaran, kalau tujuan ini tujuan penelitian ebaiknya ditulikan tujuan penelitian. Peneliti menggunakan metode kualitatif, memberikan stimulus selama 1 tahun pengajaran, wawancara, data penelitian di analisis secara deskriptif. Hasil data dari penelitian yaitu: a) perencanaan kegiatan $A O T$ b) pelaksanaan $A O T$ meningkatkan kreatifitas, mengembangkan imajinasi anak dan kepercayaan dri bagi anak c) hasil yang diperoleh dari AOT menjadikan anak yang bertanggung jawab dan berkepribadian percaya diri. berdasarkan data tersebut maka dapat disimpulkan bahwa didalam AOT dapat meningkatkan kreativitas, ide pada anak dan kepercayaan dirinya untuk menunjukan pribadinya di lingkungan sekitarnya. Berdasarkan data tersebut anak dapat merespon lawan bicara ketika anak diminta untuk membereskan tempat bermain, anak langsung sigap untuk membereskannya, serta bertanggung jawab dalam kegiatan yang ia mulai hingga selesai, ketika anak membuat kolase, ia akan menyelesaikannya hingga selesai dan menjadi suatu karya yang dapat ia pamerkan.
\end{abstract}

Kata Kunci: Seni, Terapi, Keyakinan, Tanggung Jawab.

\begin{abstract}
The ability of children to be responsible and increase self-confidence at the An-Nur Foundation Bandung is still not developed optimally, therefore researchers apply the AOT method through learning to draw. The research problems are: 1) what is the concept of AOT in the visual arts program? 2) what is the teaching and learning procedure through the AOT concept? 3) the desired outcome of the AOT concept in the visual arts program? This study aims to see how children can respond and be responsible during learning activities if the purpose of this research is to write down the research objectives. Researchers used qualitative methods, provided a stimulus for 1 year of teaching, interviews, research data were analyzed descriptively. The results of the data from the research are: a) planning AOT activities b) implementing AOT increasing creativity, developing children's imagination and confidence for children c) the results obtained from AOT making children responsible and confident personalities. Based on these data, it can be concluded that AOT can increase creativity, ideas in children, and self-confidence to show their personality in the surrounding environment. Based on this data, the child can respond to the interlocutor when the child is asked to clean up the playground, the child is immediately alert to clean it up, and is responsible for the activities he starts to finish, when the child makes a collage, he will finish it until it is finished and become a work that he can create. show off.
\end{abstract}

Keywords: Art, Therapy, Confidence, Responsibility.

How to cite (APA Style): Ningrum, N N. (2021). Art of therapy melalui proses kreatif menggambar untuk anak usia dini di kota bandung. Jurnal Penelitian Pendidikan, 21 (2), 2021. 80-87. doi: https://doi.org/10.17509/jpp.v21i2.37407 


\section{PENDAHULUAN}

Beberapa anak pada pendidikan anak usia dini yang kurang mampu bersosialisasi terhadap lingkunganya mempunyai emosi yang cenderung mudah marah. Selain itu, anak tersebut sangat sulit untuk dibina menjadi pribadi yang lebih baik. Pada saat mereka berada dalam lingkungan pembelajaran, respon yang mereka perlihatkan terhadap lingkunganya cenderung negatif, dengan prilaku yang mudah menangis, melukai teman, enggan memperkenalkan dirinya dan sulit terbuka dengan orang sekitar. Hurlock (2000:261) dalam Musyarofah, M. (2017) mengungkapkan bahwa anak yang mengikuti pendidikan prasekolah melakukan penyesuaian sosial yang lebih baik dibandingkan dengan anak yang tidak mengikuti pendidikan prasekolah. Pendidikan anak usia dini memiliki peran penting sebagai wahana dalam mengoptimalkan tumbuh kembang anak yang mencakup aspek nilai agama dan moral, fisik (motorik kasar halus), sosial, emosional, kognitif, bahasa, dan seni.

Atas dasar ini, lembaga PAUD perlu menyediakan berbagai kegiatan yang dapat mengembangkan berbagai aspek perkembangan seperti kognitif, bahasa, sosial, emosi, fisik, dan motorik. Pada semua lembaga pendidikan tentu sudah menyadari peran pendidikan dalam mencerdaskan peserta didik, walaupun dalam implementasinya belum menyentuh semua aspek kecerdasan Kurnia (2015). Lain halnya dalam kreativitas yang pada umumnya belum menjadi indikator keberhasilan lembaga pendidikan. Dengan dalih mengejar target kurikulum, terkadang lembaga pendidikan tidak segan-segan membatasi berkembangnya kreativitas anak dengan kurang memberi ruang gerak bagi berkembangnya kreativitas Rodiyana (2019). Melalui menggambar anak dapat merefleksikan kebutuhan jiwa dan fisiknya (gerakan tangan) sehingga begitu banyak manfaat dari menggambar. Secara leluasa anak dapat memilih media yang akan dipakai, sehingga melalui menggambar mereka mempunyai kesempatan bereksplorasi terhadap media tersebut. Secara visual anak dapat mengkomunikasikan permainan dan cerita yang dibangun melalui ekspresi, imajinasi dan kreasinya sehingga bentuk - bentuk gambar mereka sebenarnya adalah simbol dimaknai sebagi bentuk gagasan yang imajinatif dan kreatif yang secara kognitif membutuhkan binaan. Melalui menggambar anak dapat merefleksikan kebutuhan jiwa dan fisiknya, karena untuk anak PAUD, gambar adalah bentuk komunikasi yang divisualkan.

Terdapat banyak metode terapi yang diterapkan para guru kepada siswa-siswa nya dan salah satu nya yaitu AOT. Malchiodi (2003) berpendapat Art Therapy adalah bentuk terapi yang dilakukan dengan menggunakan potensi manusia agar dapat menjadi lebih kreatif melalui proses menghasilkan suatu karya seni. Namun, metode ini jarang digunakan didalam instansi pendidikan khususnya di PAUD, AOT Art Therapy dalam ilmu psikologi sangat sering kita mendengar istilah terapi sebagai salah satu metode untuk melakukan penyembuhan bagi individu yang mengalami gangguan psikologis. Terapi itu sendiri sangatlah beragam dan bervariatif sesuai dengan kegunaannya dan hampir setiap psikolog melakukan terapi bagi kliennya yang mengalami masalah psikologis sesuai dengan diagnosis yang telah dilakukan. Menurut AATA (American AOT Association), terapi seni itu sendiri dapat diartikan sebagai suatu kegiatan terapeutik yang menggunakan proses kreatif dalam lukisan untuk menambah baik dan menyempurnakan fisikal, mental dan emosi individu dibawah semua peringkat umur Gilroy (2012). Secara sederhana terapi seni termasuk dalam kategori terapi ekspresif yang menggunakan media warna, kapur, pensil diintergerasikan dengan terapi psikoterapeutik dan teknik proses kreatif. Melalui terapi seni ini seseorang dapat memunculkan pengalaman bawah sadar dan dari situlah perasaan akan dapat terlihat. Pengalaman bawah sadar dan perasaan tersebut diekspresikan dalam bentuk kasar yang tidak beraturan. Material seni memiliki peran penting untuk memunculkan sadar dan ketidaksadaran seseorang. Bagian terpenting dalam terapi ini pada dasarnya adalah membuat sesuatu, proses membuatnya dan apa produknya. 
Kemampuan goresan anak masih terbatas untuk membuat karyanya, anak pun belum bisa menggunakan alat gambar dengan baik. Berdasarkan kondisi tersebut, peneliti menerapkan pembelajaran menggambar bebas dalam kegiatan jurnal pagi dengan metode pembelajaran BCCT, untuk dapat meningkatkan kemampuan anak-anak dalam menggambar bebas. Masalah penelitian ini yaitu: 1) bagaimana pelaksanaan menggambar bebas dan meningkatkan motorik hlmus, di salah satu PAUD kota Bandung 2) bagaimana kontribusi kegiatan menggambar bebas terhadap perkembangan motorik hlmus anak usia dini di salah satu PAUD kota Bandung. Berdasarkan permasalahan tersebut peneliti mengadakan observasi dengan cara pre-test dan post-test lokasi penelitian dilaksanakan di pada kelompok B, wawancara, dalam menganalisis, data penelitian di analisis secara deskriptif, hasil data dari penelitian yaitu: a.) perencanaan menggambar bebas yang dilakukan melalui tahapan pre-test dan post-test, mengembangkan media menggambar bebas b.) pelaksanaan pembelajaran menggambar bebas melalui metode BCCT, dalam sentra seni dan kreativitas dengan menggunakan media gambar berupa oil pastel untuk meningkatkan kegiatan yang menunjang kelenturan motorik hlmus sebagai pembelajaran menulis dan bertujuan untuk meningkatkan kreatifitas dan mengembangkan imajinasi anak c.) hasil yang di peroleh dari pembelajaran menggambar bebas dengan menggunakan oil pastel ternyata adanya peningkatan dalam proses menggambar bebas. Berdasarkan data tersebut maka dapat disimpulkan bahwa didalam penggunaan media gambar berupa oil pastel dapat meningkatkan kreativitas dan menguatkan otot tangan terhadap anak.

Terdapat Penelitian yang serupa yang membahas Art Therapy oleh Wong \& Kurnianingrum (2018) dalam jurnal tersebut membahas bagaimana pengaruh Art Therapy untuk meningkatkan SelfEsteem bagi anak usia dini dengan mengangkat pembahasan yang menyeluruh tentang masalahmasalah yang di hadapi anak dalam berprilaku, belajar dan perkembangan. Namun dalam penelitian yang penulis lakukan saat ini Art Therapy berfokus hanya dalam pembahasan meningkatkan respon anak dalam bercakap, dan sikap bertanggung jawab dalam mengerjakan hal yang anak mulai kerjakan hingga selesai.

\section{METODE PENELITIAN}

Metode penelitan yang digunakan adalah deskriptif, populasi dan sampel. Dalam penelitian ini menggunakan sample purposive yang memfokuskan pada informan terpilih yang kaya dengan kasus untuk studi yang bersifat mendalam Wijayanti (2010). Maka data yang diperlukan untuk penelitian ini adalah melalui wawancara, observasi, maupun studi dokumentasi, sumber data adalah sumber objek dari mana data itu diperoleh. Menurut Sugiyono (2019:127) sampel adalah bagian dari jumlah dan karakteristik yang dimiliki oleh populasi tersebut. Prosedur pengambilan sampel yang digunakan dalam penelitian ini adalah non-probabilitay dengan teknik purposive sampling. Populasi sampel nya adalah 4 orang siswa tepatnya di Yayasan An-Nur Kota Bandung

Penelitian ini menafsirkan dan menguraikan data yang bersangkutan dengan situasi yang sedang terjadi, sikap serta pandangan yang terjadi di dalam suatu masyarakat, pertentangan antara dua keadaan atau lebih, hubungan antar variable yang timbul, perbedaan antar fakta yang ada serta pengaruhnya terhadap suatu kondisi, dan sebagainya.

\section{HASIL DAN PEMBAHASAN}

Setelah dibuka pembahasan mengenai AOT, muncul suatu masalah dimana para tenaga pendidik di beberapa sekolah PAUD merasa ada beberapa siswa bimbingan mereka yang sulit untuk bersosialisasi dengan lingkungannya yang disebabkan karena siswa tersebut sangat pendiam. Dengan begitu, secara tidak langsung dapat membentuk anak tersebut menjadi kurang percaya diri dengan 
berbagai hal yang dapat mengakibatkan sulitnya berinteraksi dengan teman-teman nya dan enggan untuk menyelesaikan pekerjaan yang sudah dimulainya.

\section{Hasil}

Hasil perbandingan gambar dan gaya bercerita anak setelah dilakukan Art of therapy selama 1 tahun yang diadakan di Yayasan An-Nur Bandung.

Hasil penelitian yang didapatkan terhadap objek TA sebelum yaitu memulai masuk kelas A ananda TA sangat tidak mau bersosialisasi, ketika di dekati temannya ananda ayu pergi ke orang tuanya dan menangis, hingga tidak mau sekolah, kepercayaan diri nya sangat kurang sekali, tidak mau ngengerjakan tugas di sekolah serta enggan berbicara banyak dengan lawan bicaranya. Setelah diterapkannya metode teraphy ini ananda TA selain bentuk karya yang semakin bagus, kepercayaan untuk menunjukan siapa dirinya kepada orang lain dan gurunya semakin meningkat, ia mampu bertanya akan hal yang ia ingin tau dan mampu bernegosiasi dengan teman-temannya saat bermain bersama, semakin meningkat ketika mengerjakan tugas yang di berikan guru dan orang tuanya. Perbandingan hasil Art Therapy karya TA dapat dilihat pada Gambar 1.

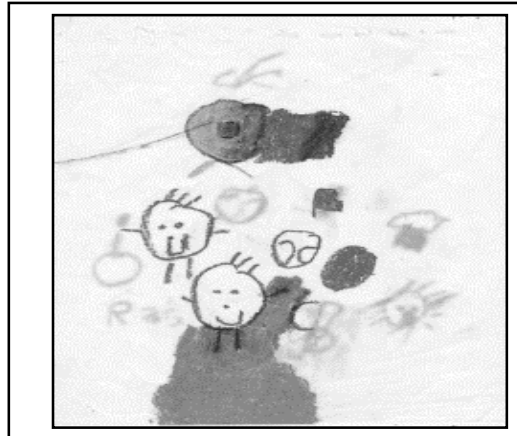

Sebelum diterapkan Art Theraphy

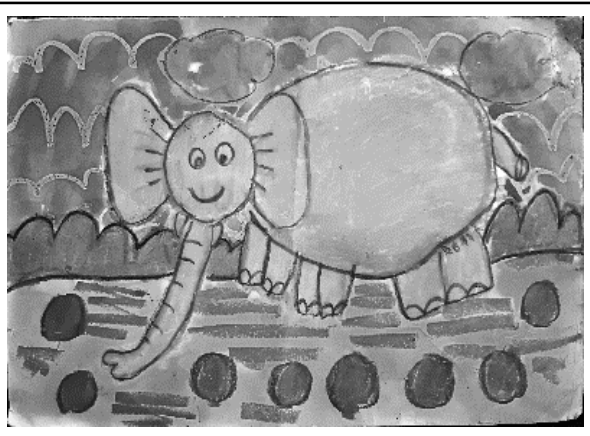

Setelah diterapkan Art Theraphy

Gambar 1. Art Therapy karya TA (Sumber: Dokumentasi pribadi)

Hasil penelitian terhadap objek Nouval sebelum memulai masuk kelas A ananda Nouval sering mengganggu anak yang lain sering memukul temannya tetapi begitu ananda Nouval diperintah untuk memperkenalkan diri di depan kelas ia sangat ketakutan dan tidak mampu berkomunikasi lebih dalam. Setelah berjalan 6 bulan therapy ini ananda naufal masih enggan bersosialisasi Bersama temantemannya, sehingga masih menyulitkan guru ketika di kelas saat pembagian kelompok bermain, tetapi nouval sudah dapat menyelesaikan tugas dan pekerjaan yang ia mulai kerjakan dari awal hingga akhir, dengan begitu ananda Naufal masih dalam tahap pemberian stimulus hingga saat ini. Perbandingan hasil Art Therapy karya Nouval dapat dilihat pada Gambar 2.

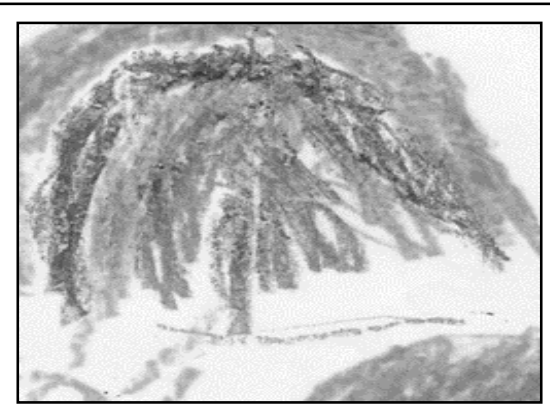

Sebelum diterapkan Art Therapy

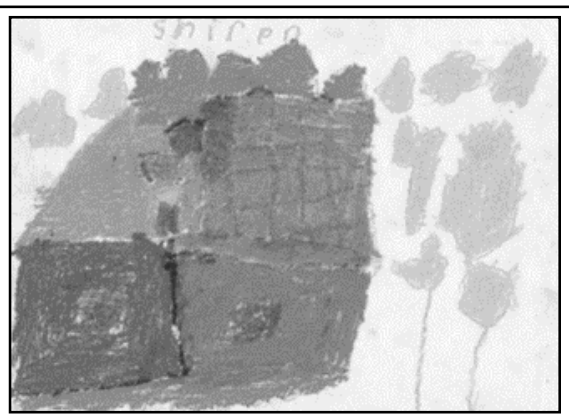

e-ISSN: 2541-4135| p-ISSN: $1412-565 \times$ X

Copyright (8) authers, 2021 
Gambar 2. Art Therapy karya Nouval (Sumber : dokumentasi pribadi)

Hasil penelitian yang didapatkan terhadap objek Khirgiz sebelum memulai masuk kelas A ananda khirgiz menjadi pribadi yang pendiam tidak mau berbicara dan bermain bersama temannya, bahkan mengenalkan nama pada gurunya pun ia tidak mau serta sulit mengerjakan perintah atau tugas yang diberikan oleh guru dan orang tuanya. Setelah berjalan 6 bulan therapy ini ananda khirgiz masih enggan bersosialisasi bersama teman-temannya, sehingga masih menyulitkan guru ketika di kelas saat pembagian kelompok bermain, dengan begitu ananda Khirzig masih dalam tahap pemberian stimulus hingga saat ini, namun dalam menyalurkan tanggung jawab untuk menyelesaikan tugasnya ananda khirgiz sudah sangat baik. Hasil Art Therapy karya Khirgiz dapat dilihat pada Gambar 3.

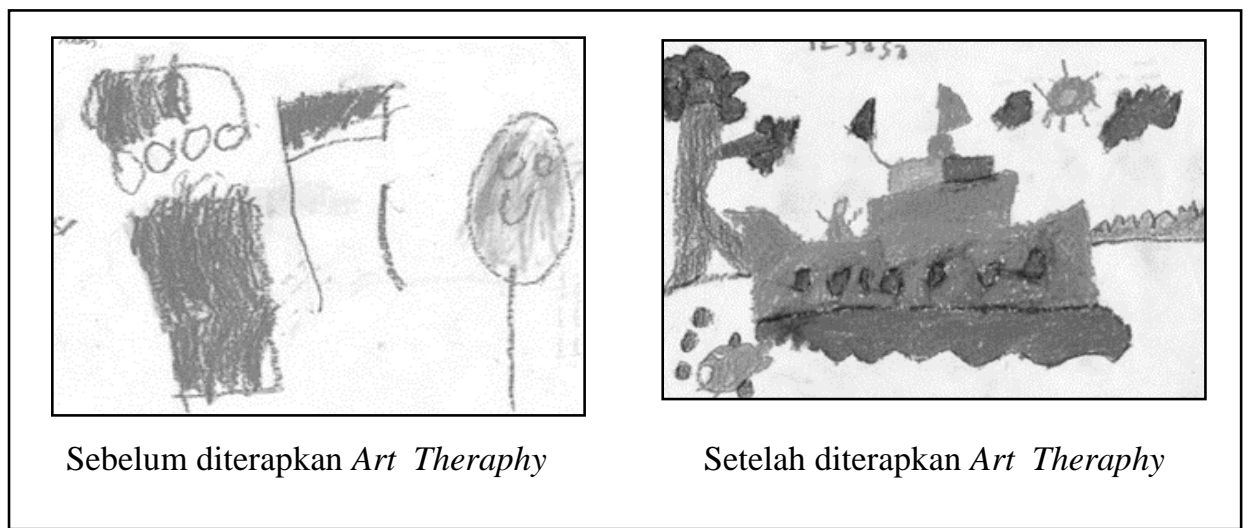

Gambar 3. Art Therapy karya Khirgiz (Sumber : dokumentasi pribadi)

Hasil penelitian yang didapatkan terhadap objek CC sebelum memulai masuk kelas A ananda CC menjadi pribadi yang tidak mau belajar bersama, dengan karya nya yang cukup unik, ananda CC malu untuk memperlihatkan dan bercerita kepada guru dan teman-temannya. Hasil penelitian yang didapatkan terhadap objek CC sesudah dilakukannya Art Teraphy selama 6 bulan, ananda CC sedikit bisa bersosialisasi bermain bersama teman-temannya dan dapat menunjukkan apa yang ia hasilkan terhadap gurunya, serta mengerjakan tugas dari awal hingga dapat menuntaskan semua pekerjaanya hingga selesai. Hasil Art Therapy karya CC dapat dilihat pada Gambar 4.

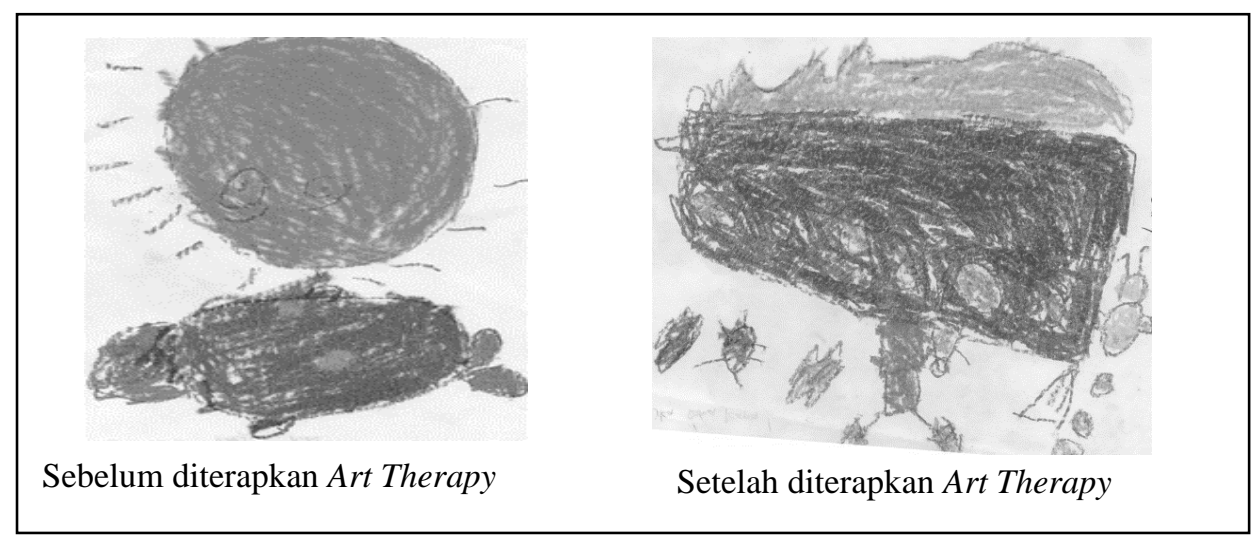

Gambar 4. Art Therapy karya CC (Sumber : dokumentasi pribadi) 


\section{Pembahasan}

Pada penelitian sebelumnya Alvina, dkk (2018) dipaparkan bahwa bahwa Art Therapy dapat meningkatkan self-esteem pada anak, dimana fokus pembahasannya lebih diranah self-awerness dalam unsur kognitif

Dalam penelitian yang penulis lakukan ada kesamaan dalam hasil dimana Art Therapy dapat meningkatkan unsur kognitif anak dalam merespon lawan bicara dan menanamkan nilai tanggung jawab ketika anak melakukan kegiatan sampai tuntas dari awal hingga selesai. Adapun hasil penelitian dilapangan berkenaan dengan Art Therapy di Yayasan An-Nur kota Bandung adalah sebagai berikut:

1. Anak akan senang jika diterima di dalam lingkungan teman-teman sebayanya. Mereka senang melakukan kerja sama serta saling memberikan semangat pada temanteman lainnya. Anak membangun konsep pada dirinya melalui interaksi komunikasi sosial yang terjadi di sekolah. Respon dirinya akan membangun kepuasan melalui sebuah penghargaan diri saat diberikan sebuah kesempatan untuk bisa bekerja sama dengan teman-temannya, dengan begitu pula anak dapat terpacu dalam mengerjakan tugas atau mengerjakan kegiatan yang ia mulai hingga selesai, secara tidak langsung membangun sebuah tanggung jawab dalam melakukan hal bagi anak akan terbentuk dengan sendirinya

2. Kondisi anak yang perlu terapi adalah kondisi yang kurang percaya diri, ragu untuk mengemukakan pendapat, sulit merespon lawan bicaranya dan memiliki jiwa yang individual serta sulit mengerjakan tugas atau kegiatan hingga tuntas. Adapun kondisi anak yang memenuhi kriteria standar bersosialisasi yaitu anak yang berani bertangung jawab atas apa yang telah dilakukan, berani mengemukakan pendapat, merespon siapapun yang menjadi lawan bicaranya dan bisa bersosialisasi terhadap lingkunganya. Prosedur yang digunakan peneliti untuk melakukan terapi adalah menggambar sambil bercerita yang bertujuan untuk meningkatkan daya ingat anak, memperkenalkan bentuk dan gambar hewan karna menjadi salah satu metode untuk mengetahui karakter anak. Dengan begitu, hal tersebut menjadi rumus temuan peneliti untuk meningkatkan rasa percaya diri pada anak.

3. Setelah dilakukan penelitian terhadap beberapa anak, peneliti menemukan terapi yang cocok diterapkan pada anak yang berusia 4-5 tahun di Yayasan An-Nur, dengan begitu, dapat di simpulkan dari penjelasan diatas bahwa anak cenderung menyukai hal-hal yang baru dan atraktif.

\section{KESIMPULAN}

Dengan begitu dapat kita simpulkan bahwa Art of Therapy bisa menjadi salah satu media pembelajaran Pendidikan anak usia dini dan dapat menjadikan salah satu terapi untuk meningkatkan daya respon anak dalam menempatkan diri bersama lawan bicaranya dan mampu meningkatkan rasa tanggung jawab pada diri sendiri untuk menyelesaikan hal yang sudah ia mulai hingga tuntas, serta meningkatkan kreatifitas anak ketika menumpahkan ide dan imajinasi dalam bentuk gambar, anak juga dapat bercerita serta menceritakan apa yang mereka tumpahkan kedalam kertas, dengan begitu komunikasi dapat dibangun secara komunikatif antara guru, orang tua dan anak akan terjalin lebih baik.

\section{DAFTAR PUSTAKA}

Fitra, A. (2016). Pembelajaran Menggunakan Metode Think-Pain Share Pada Pokok Bahasan Perpangkatan Bilangan Bulat Untuk Meningkatkan Kemampuan Pemecahan Masalah Siswa Di Kelas VII SMP Kemala Bhayangkari 1 Medan. Jurnal Mantik Penusa, 19(1).

Gilroy, A., Tipple, R., \& Brown, C. (Eds.). (2012). Assessment in art therapy. Routledge.

Kurnia, S. D. (2015). Pengaruh kegiatan painting dan keterampilan motorik halus terhadap kreativitas anak usia dini dalam seni lukis. Jurnal Pendidikan Usia Dini, 9(2), 285-302. 
Malchiodi, C. A. (2003). Expressive arts therapy and multimodal approaches. Handbook of art therapy, 106-117.

Musyarofah, M. (2017). Pengembangan aspek sosial anak usia dini di taman kanak-kanak Aba IV Mangli Jember tahun 2016. INJECT (Interdisciplinary Journal of Communication), 2(1), 99-122.

Ningrum, N. N. Pembelajaran Menggambar Melatih Motorik Halus Dan Sosial Bagi Anak. Irama: Jurnal Seni Desain Dan Pembelajarannya, 2(2), 18-22.

Rodiyana, S. (2019). Efektivitas Kegiatan Bermain Finger Painting Terhadap Pengembangan Kreativitas Anak Kelompok B di TK Franthikah.

Sugiyono., 2006., Metode Penelitian Kuantitatif, Kualitatif dan R \& D.Bandung:Alfabeta.

Wijayanti, E. M. (2010). Penggunaan metode al-barqy untuk membaca huruf hijaiyah pada anak tunarungu wicara kelas VIII SMP di SLB B YRTRW Surakarta tahun ajaran 2009/2010.

Wong, A., \& Kurnianingrum, W. (2018). Penerapan art therapy untuk meningkatkan self-esteem anak usia middle childhood. Jurnal Muara Ilmu Sosial, Humaniora, Dan Seni, 2(1), 198-204. 